\title{
CONCEPT, MOTIVES AND CHANNELS OF DIGITAL SHADOW ECONOMY: CONSUMERS' ATTITUDE
}

\author{
Ligita GASPARÉNIENE் ${ }^{1}$, Rita REMEIKIENE ${ }^{2}$, \\ Friedrich Georg SCHNEIDER ${ }^{3}$
}

\author{
1,2 Department of Banking and Investment, Economics and Finance Management Faculty, \\ Mykolas Romeris University, Ateities g. 20, LT 08303, Vilnius, Lithuania \\ ${ }^{3}$ Department of Economics, Institute of Economic Policy, \\ Johannes Kepler University of Linz, A-4040 Linz-Auhof, Austria, \\ E-mails: 'ligitagaspareniene@mruni.eu; ${ }^{2}$ rita.remeikiene@mruni.eu (corresponding author); \\ 33Friedrich.Schneider@jku.at
}

Received 04 February 2016; accepted 15 July 2016

\begin{abstract}
The purpose of this article is to define the concept of digital shadow economy and identify its determinants and channels from consumers' position. In order to fulfil the defined purpose, the method of snowball sampling was employed. The results of the research revealed that consumers interpret digital shadow economy as an illegal operation in the Internet space, which generates illegal money flows for commodity/service providers or purchasers, and deprives legal traders/service providers from the revenue that could be officially accounted, calculated and declared. E-shops, social networks and websites are the channels, most commonly engaged for acquisition of goods/services in digital space; the categories of goods/services acquired by these channels include clothing and footwear, trips and entertainment, cosmetics and perfume. Purification of the concept of digital shadow economy from consumers' position allowed to define the concept of digital shadow economy, which is a significant contribution to the evolution of the theory of digital shadow economy, and can enable to develop an instrument for measuring the scopes of digital shadow economy in further research.
\end{abstract}

Keywords: digital shadow economy, consumers, concept of digital shadow economy, snowball sampling, motives/factors of digital shadow economy, shadow economy.

JEL Classification: E26, H26, K42, O17.

\section{Introduction}

With an attraction of opportunities, including easy accessibility and use of technologies, variety of goods and services on sale, and convenient delivery terms, more and more consumers start preferring online shopping to traditional one. Nevertheless, distinctive features of digital trade, primarily, anonymity (Ingram, Hinduja 2008; Williams et al. 2010), and difference between corporate and personal (Shang et al. 2008; Williams et al. 2010), determine conscious or unconscious consumers' involvement in digital shadow trade. Since consumers generate the demand for goods and services traded online, they 
can be considered as the main party of digital shadow economy. Hence, in order to develop efficient measures of digital shadow economy prevention, first of all, it is purposeful to research how the consumers, who purchase goods/services online, perceive the phenomenon of digital shadow economy, what determinants generate the demand for acquisition of goods/services from digital shadow markets, and what channels are employed for the order and delivery of goods/services from digital space.

Previous scientific research on the topic of consumers' involvement in digital shadow economy is basically limited with the studies on particular forms (e-fraud - Blackledge, Coyle 2010; Akintoye, Araoye 2011; Vlachos et al. 2011; digital piracy - Williams et al. 2010; Camarero et al. 2014; Yu et al. 2015) or determinants (Shang et al. 2008; Williams et al. 2010; Higgins et al. 2008; Yu et al. 2015) of consumers' illegal behaviour online. However, the concept, features and channels of digital shadow economy from consumers' position have hardly been analysed in complex. The research of this type would provide a clearer view of what the phenomenon of digital shadow economy refers to from consumers' attitude, and might contribute to the development of the measures of digital shadow economy reduction. Considering the reasons explicated above, this article is aimed at definition of the concept of digital shadow economy and identification of its features and channels from consumers' position. For the fulfilment of the defined aim, the following objectives have been raised: 1) to analyse theoretical concepts and interpretations of digital shadow economy; 2) to review the literature on the features and channels of digital shadow consumption; 3) to select and present the methodology of the research; 4) to introduce the results of the empirical research. The methods of the research include scientific literature analysis and consumer survey based on snowball sampling method.

\section{Theoretical concepts of digital shadow economy}

The concept of digital shadow economy can be derived from the concept of shadow economy, which, in its broad sense, refers to unreported revenues earned either from production and sales of legal (not forbidden by legal regulations) goods and services, or from monetary or barter transactions (Schneider, Buehn 2013; Schneider et al. 2015). Hence, "shadow economy includes all economic activities that would generally be taxable were they re-ported to the tax authorities" (Schneider, Buehn 2013: 3). Following the general concept of shadow economy, digital shadow economy in its broad sense can be defined as unreported revenues earned in the Internet (e-space, online) either from sales of legal (not forbidden by legal regulations) goods and services, or from monetary transactions completed by employing exceptionally electronic measures of settlement.

As, according to Holz et al. (2009), volatility and rapid advance of technologies make understanding of digital shadow economy rather complicated, scientific literature is rich in the variety of different interpretations of digital shadow economy, in accordance with the nature, general purpose or the subjects of this phenomenon. The analysis of the scientific literature has enabled to systematise the terms of digital shadow economy by distinguishing three basic term groups:

- The terms reflecting the nature of digital shadow activities; 
- The terms reflecting the role of a supplier as an active subject;

- The terms reflecting the role of a consumer as an active subject.

Since this research is aimed at definition of the concept of digital shadow economy from consumers' position, the terms attributable to the second group will not be discussed further in this article.

In the group of the terms that reflect the nature of digital shadow activities, the term digital underground economy refers to hidden (unregistered) profit-driven online business (Moore et al. 2009; Herley, Florencio 2010; Yip et al. 2012). It slightly differs from the term illegal digital economy, which stresses violation of the established legal regulations on digital business rather than a pursuit for profit (Arango, Baldwin-Edwards 2014). The term unreported digital economy reveals evasion of tax contributions in digital business (Feige 2007, 2012; Gaertner, Wenig 2012). Finally, the term digital unrecorded economy points out circumvention of the defined regulations and requirements on reporting business or trade activities performed in the Internet (Karanfil 2008; Feige, Urban 2008).

In the group of the terms reflecting the role of a consumer as an active subject, the terms of e-fraud, digital piracy and dysfunctional consumer behaviour online can be distinguished. The term $e$-fraud refers to the activities of obtaining money illegally using the Internet (McMillan Dictionary 2015). With reference to Vlachos et al. (2011), most of e-fraud cases involve consumers, seeking to purchase particular items (e.g. IT, mobile phones, music and entertainment devices, etc.) online. The term digital piracy (or e-piracy) is defined as the illegal or unauthorized copying/downloading of particular copyrighted content (Castro et al. 2009; Camarero et al. 2014). Finally, the term dysfunctional consumer behaviour online means consumers' actions in the Internet that violate the generally accepted norms of conduct in trade (Harris, Daunt 2013), for instance, purchasing of a product with the intention to return it for reimbursement, making a fraudulent or illegitimate claim for financial gain, etc. (Vlachos et al. 2011; Amasiatu, Shah 2014).

Summarising, it can be stated that digital shadow economy in its general sense refers to illegal, unreported or unrecorded activities online, driven by profit, tax evasion, gain or circumvention of legal regulations. Considering the theoretical interpretations of digital shadow economy, cybercriminal activities should be excluded from the context of the concept of digital shadow economy as they refer to criminal offenses rather than to economy generators. In order to ascertain how the phenomenon of digital shadow economy is perceived by consumers and whether consumers distinguish digital shadow economy from criminal activities in e-space, the following concepts of the analysed phenomenon can be proposed for the empirical research:

- Digital shadow economy is a part of shadow economy, when illegal profit-driven online trade or service provision is performed. The activities of digital shadow economy have the trend to be of repeated or non-repeated nature with or without changing IP addresses/computer networks;

- Digital shadow economy refers to global networks emerging in closed Internet forums and promoting chains of e-crimes, including bank attacks, payment card crimes, identity steals and other Internet intrusions; 
- (Un)interrupted, financial gain driven provision of particular commodities or services in the remote space, performed without activity registration and causing damage to an officially registered subject, who provides similar commodities or services;

- Digital shadow economy is an illegal operation in the Internet space, which generates illegal money flows for commodity/service providers or purchasers, and deprives legal traders/service providers from the revenue that could be officially accounted, calculated and declared;

- Digital shadow economy refers to the trade in e-space, performed without paying any taxes to the state budget, excluding purely criminal activities such as drug trafficking, prostitution.

The proposed concepts of digital shadow economy will be presented for consumers' evaluation in order to define the concept of the researched phenomenon from consumers' position.

\section{The determinants and channels of digital shadow consumption: theoretical background}

The analysis of the scientific literature has revealed that the determinants of acquisition of goods/services from digital shadow markets fall into the groups of macroeconomic, economic, psychological, legal and consumer benefit determinants. In the group of macroeconomic determinants, the experts from Lithuanian Free Market Institute (LFMI) emphasise the significance of the overall macroeconomic situation in the country. It is proposed that increased accessibility of economic activities to physical entities (LFMI 2014), reduction of unemployment rate (Williams et al. 2010; LFMI 2014), increased wages (Schneider et al. 2010; Putniņš, Sauka 2014; LFMI 2014) as well as promotion of general advancement of the country (including IT advancement) (Ingram, Hinduja 2008; Amasiatu, Shah 2014; Camarero et al. 2014) could significantly contribute to reduction of the scope of shadow economy (including digital shadow activities) since these measures would make legal activities more attractive in comparison to illegal ones.

Economic determinants of the demand for acquisition of goods/services from digital shadow markets cover low costs of digital storage, i.e. opportunities for a consumer to obtain a product or service online round-the-clock (Ho, Weinberg 2011; Sirkeci, Magnusdottir 2011), lower price of goods/services sold online in comparison to those sold in traditional shops (Ho, Weinberg 2011; Williams et al. 2010; Yu et al. 2015) and availability of consumer credits (e.g. short-time bank credits, fast credits) that serve as a source of the necessary funds for consumer purchases (Šukyte் 2010; Williams et al. 2010).

In the group of psychological determinants, low level of public morale, especially related to tax paying, i.e. low tax morale, is considered as one of the most significant factors that determine entities' involvement in different forms of shadow economy including shadow activities online (Alm, Torgler 2011; Williams 2014; Williams, Horodnic 2015 and others). Low tax morale alongside with low level of public self-consciousness determine social acceptability of illegal activities online within particular social circle or society (Williams 2014; Amasiatu, Shah 2014). 
Poor measures of illegality discouragement, i.e. low probability of detection of a fact of a purchase obtained from an unregistered juridical or unofficially performing physical entity (Waterman et al. 2007; Ho, Weinberg 2011), lack of regulations on cybercrime prevention (Levin et al. 2007), insufficiency of the professionals (officials) with cybercrime detection abilities (Waterman et al. 2007; Ho, Weinberg 2011; Bossler, Holt 2012) and poor regulation of IT sector (Bossler, Holt 2012; Mayayise, Osunmakinde 2014), also provide a favourable environment for illegal digital trade. Although some recent studies on explanation of shadow economy (Williams et al. 2014; Williams, Vorley 2014; Williams, Horodnic 2015) suggest that direct controls are not, as earlier expected, the most important tools of shadow economy combating and prevention (i.e. undeclared economy arises due to the lack of alignment between the codified laws (formal institutions) and social values (informal institutions)), legal determinants of digital shadow economy such as low probability of detection of a fact of a purchase obtained from unregistered juridical or unofficially performing physical entity online, weak legal framework with the lack of regulations preventing illegal activities online, and poor regulation and control of IT sector will be included the empirical research considering the findings of the earlier scientific studies (Levin et al. 2007; Waterman et al. 2007; Ho, Weinberg 2011; Bossler, Holt 2012; Mayayise, Osunmakinde 2014, etc.).

What concerns the channels of digital shadow consumption, the analysis of the scientific literature has disclosed that engagement of particular channels for acquisition of goods/ services online means exploitation of the remote spaces such as online shops, online service provision websites, social networks (Hafezieh et al. 2011; Levi, Williams 2013; Amasiatu, Shah 2014), e-advert and e-auction sites (Vlachos et al. 2011; Dion 2011; Smith 2015). Hence, the channels mentioned above will be proposed for consumers' assessment in the empirical part of the research.

Summarising, the determinants of the demand for acquisition of goods/services from digital shadow include unfavourable macroeconomic situation in the country, linked to the lack of accessible economic activities, high rate of unemployment, low wages and general technological advancement; economic drivers, primarily low costs of digital data storage, lower prices of the goods/services offered online and easy access to shortterm credits; psychological factors such as low level of tax morale and stereotypical negative attitude towards public authorities; imperfections of legal framework related to low probability of detection of a fact of a purchase obtained from an unregistered juridical or unofficially performing physical entity, lack of regulations on cybercrime prevention, lack of professionals with cybercrime detection abilities and poor regulation of IT sector; and consumer benefit emerging as convenience to make purchases roundthe-clock without leaving home, anonymity while making purchases online, lack of opportunities to obtain a desired product in the local market and time saving in comparison to acquisition of a product/service in the local market. The channels of acquisition of goods/services in digital space include remote spaces such as online shops (e-shops), social networks and platforms as well as online trade/service provision websites, e-advert and e-auction sites. The above-introduced theoretical determinants of acquisition of goods/services from digital shadow as well as the channels of digital shadow consump- 
tion identified in earlier scientific studies will be proposed for consumers' consideration in the empirical part of this research. Alongside with the channels of digital shadow consumption, we find it purposeful to identify what categories of goods/services are most commonly acquired via these channels, although as to our knowledge, scientific literature does not contain any previous research on this topic. The methodology and the results of the empirical research have been introduced in further sections of this article.

\section{The methodology of the empirical research}

In order to fulfil the defined aim of the research, the method of snowball sampling was employed for consumers' survey. This method is commonly applied for qualitative research due to ensured opportunities to achieve a hidden target population (Atkinson, Flint 2001).

The questionnaire for the survey was composed of three structural parts: the first part was developed to establish demographic characteristics of consumers who operate in digital shadow markets; the second part covered the concepts of digital shadow economy proposed for consumers' evaluation in Likert scale; finally, the third part was developed to establish the determinants of acquisition of goods/services from digital shadow, to identify the acquisition channels and find out what categories of goods/services are most commonly acquired via these channels.

While estimating the sample of the survey, it was presumed that the total amount of population in Lithuania makes 3 million people, 66 percent of whom have Internet access (Lithuanian Department of Statistics 2014). In order to separate Internet consumers from the consumers who purchase goods/products in e-space, the criterion of e-purchase was applied, i.e. only the questionnaires filled in by the respondents, who confirmed having acquired a good or a service online, were selected for further processing of the survey results. The sample was estimated by using Sample Size Computation for Population Proportion Confidence Interval (ECS 2016):

$$
n=\frac{\left[t^{2} \times p \times(1-p)\right]}{e^{2}},
$$

where: $n=$ sample size; $t=$ the critical value of the normal distribution at $\alpha / 2$ (e.g. for a confidence level of $95 \%, \alpha$ is 0.05 and the critical value is 1.96 ); $p=$ sample proportion (this can often be determined by using the results from a previous survey, or by running a small pilot study; when the researchers are unsure, it is best to use $50 \%$, which is conservative and gives the largest sample size); $e=$ percent error rate $(5 \%$ for 95 percent confidence level).

Therefore, we obtain: $n=1.96 * 1.96 * 0.5 * 0.5 / 0.05 * 0.05=384.16$ or 384 individuals.

However, the real number of the respondents, available for the survey, composed 368 people, which determined a slight increase in the error rate up to 5.11 percent. The survey was carried out during the period of August - November, 2015, engaging the tools of e-survey development. The obtained data was processed with SSPS and Microsoft Excel software. 


\section{The results of the empirical research}

The survey has enabled to identify the following demographic characteristics of consumers in digital shadow economy:

- by age, the majority of consumers, who form the demand in digital shadow economy, is composed of young people aged from 16 to 29 (69.8 percent of the total number of survey participants);

- by occupation, the biggest part of the respondents ( 46.7 percent of the total number of survey participants) was composed of students; experts made 18.2 percent, employees and IT professionals - respectively 7.9 and 7.6 percent of the respondents;

- by income, the majority of the respondents (25.5 percent of the total number of survey participants) fall into the group of consumers, whose earnings make from 501 to 1000 EUR per month; 21.2 percent of the respondents pointed out not earning any income, which can be explained by a large number of students ( 46.7 percent of the respondents) among the total number of survey participants;

- by education, nearly a half of the respondents (45.9 percent of the total number of survey participants) indicated having higher education; slightly smaller part - 39.4 percent of the respondents - pointed out having secondary education;

- by gender, the survey involved 31.3 percent of male and 63 percent of female;

- by marital status, 41.3 percent of the respondents indicated living with their parents whereas 17.7 percent are married with children.

With reference to Malhotra and Birks (2003), who state that 0.6 stands for the lowest critical value of questionnaire reliability in economic research, 0.6 was selected as the lowest critical value of Cronbach alpha coefficient for this research. Cronbach alpha coefficient, calculated for the second part of the questionnaire, was equal to 0.6, which proposes that the survey questions reflect the researched dimension with appropriate accuracy. Kendall's coefficient of concordance was equal to 0.061, and value $p$ was equal 0.000 , which discloses weak, but statistically significant compatibility of respondents' opinions. In Table 1, the mean ranks (i.e. average values of the elements in the data set), estimated for the proposed concepts of digital shadow economy, have been presented with a view to defining the concept of digital shadow economy from consumers' position and using it for the development of an instrument for measuring digital shadow economy in further research.

The concepts with average ranks of 3.5 and higher are considered accurately reflecting the nature of digital shadow economy from consumers' position whereas the ones with average ranks of 3.49 and lower are treated as poorly reflecting the nature of the researched phenomenon. The rank limit of 3.5 points remains the same for the entire research.

The results of the empirical research propose that consumers are inclined to distinguish criminal activities (drugs, prostitution, credential steals, etc.) from illegal economic activities, which also violate established legal norms and regulations. The participants of the survey clearly perceive that the activities of digital shadow economy are performed exceptionally in electronic space without official registration of business and evading tax payment. 
Table 1. Mean ranks for the proposed concepts of digital shadow economy: consumers' attitude (compiled by the authors with reference to the survey results)

\begin{tabular}{|c|c|c|c|c|c|}
\hline No. & Proposed concept of digital shadow economy & $\begin{array}{c}\text { Mean } \\
\text { rank }\end{array}$ & Mode & Minimum & Maximum \\
\hline 1 & $\begin{array}{l}\text { Digital shadow economy is a part of shadow economy, } \\
\text { when illegal profit-driven online trade or service } \\
\text { provision is performed. The activities of digital } \\
\text { shadow economy have the trend to be of repeated } \\
\text { or non-repeated nature with or without changing IP } \\
\text { addresses/computer networks. }\end{array}$ & 3.48 & 4 & 1 & 5 \\
\hline 2 & $\begin{array}{l}\text { Digital shadow economy refers to global networks } \\
\text { emerging in closed Internet forums and promoting } \\
\text { chains of e-crimes, including bank attacks, payment } \\
\text { card crimes, identity steals and other Internet } \\
\text { intrusions. }\end{array}$ & 3.19 & 3 & 1 & 5 \\
\hline 3 & $\begin{array}{l}\text { (Un)interrupted, financial gain driven provision of } \\
\text { particular commodities or services in the remote } \\
\text { space, performed without activity registration and } \\
\text { causing damage to an officially registered subject, who } \\
\text { provides similar commodities or services. }\end{array}$ & 3.78 & 4 & 1 & 5 \\
\hline 4 & $\begin{array}{l}\text { Digital shadow economy is an illegal operation in } \\
\text { the Internet space, which generates illegal money } \\
\text { flows for commodity/service providers or purchasers, } \\
\text { and deprives legal traders/service providers from the } \\
\text { revenue that could be officially accounted, calculated } \\
\text { and declared. }\end{array}$ & 3.83 & 4 & 1 & 5 \\
\hline 5 & $\begin{array}{l}\text { Digital shadow economy refers to the trade in e-space, } \\
\text { performed without paying any taxes to the state } \\
\text { budget, excluding purely criminal activities such as } \\
\text { drug trafficking, prostitution, etc. }\end{array}$ & 3.53 & 4 & 1 & 5 \\
\hline
\end{tabular}

Cronbach alpha coefficient, calculated for the third part of the questionnaire, was equal to 0.823 , which proposes that the survey questions reflect the researched dimension with appropriate accuracy. Kendall's coefficient of concordance was equal to 0.133 , and value $p$ was equal 0.000 , which discloses weak, but statistically significant compatibility of respondents' opinions. The mean ranks, estimated for the determinants of acquisition of goods/services from digital shadow markets, have been introduced in Table 2. The data in Table 2 reveals that, in the group of macroeconomic and economic determinants, lower price is the most significant determinant (mean rank is equal to 4.08) of acquisition of goods/services from digital shadow markets. The other weighty determinants in this group include unfavourable economic situation in the country (mean rank is equal to 3.67) and technological advancement (mean rank is equal to 3.66).

In the group of miscellaneous determinants, IT advantages (mean rank is equal to 4.03), time saving in comparison to acquisition of a product/service in the local market (mean rank is equal to 3.95) and lack of opportunities to obtain a desired product in the local market (mean rank is equal to 3.95 ) can be treated as significant determinants of 
acquisition of goods/services from digital shadow markets with their mean ranks exceeding 3.50 points. In general sense, the factors mentioned above might, undoubtedly, be attributed to the determinants of the overall e-trade. Nevertheless, according to the consumers, they serve as extra motives to acquire products or services from illegal traders since they enable exploiting the advantages provided by e-space.

Table 2. The determinants of acquisition of goods/services from digital shadow markets (compiled by the authors with reference to the survey results)

\begin{tabular}{|c|c|c|c|c|}
\hline Determinant/determinant group & $\begin{array}{l}\text { Mean } \\
\text { rank }\end{array}$ & Mode & Minimum & Maximum \\
\hline \multicolumn{5}{|c|}{ Macroeconomic and economic determinants } \\
\hline Lack of accessibility of economic activities & 3.02 & 3 & 1 & 5 \\
\hline $\begin{array}{l}\text { Unfavourable economic situation in the country (high rate } \\
\text { of unemployment, low wages) }\end{array}$ & 3.67 & 4 & 1 & 5 \\
\hline $\begin{array}{l}\text { Technological advancement (simple access to the Internet, } \\
\text { quality of software and hardware, bearable costs of mobile } \\
\text { and Internet connection) }\end{array}$ & 3.66 & 4 & 1 & 5 \\
\hline Low costs of digital data storage & 3.45 & 4 & 1 & 5 \\
\hline Lower price & 4.08 & 4 & 1 & 5 \\
\hline $\begin{array}{l}\text { Spread of financial innovations (e.g. accessibility of a short- } \\
\text { term credit online) }\end{array}$ & 3.26 & 3 & 1 & 5 \\
\hline \multicolumn{5}{|l|}{ Psychological determinants } \\
\hline Low level of tax morale & 3.45 & 3 & 1 & 5 \\
\hline Stereotypical negative attitude towards public authorities & 3.38 & 3 & 1 & 5 \\
\hline \multicolumn{5}{|l|}{ Legal determinants } \\
\hline $\begin{array}{l}\text { Low probability of detection of a fact of a purchase } \\
\text { obtained from unregistered juridical or unofficially } \\
\text { performing physical entity without paying VAT }\end{array}$ & 3.26 & 3 & 1 & 5 \\
\hline $\begin{array}{l}\text { Weak legal framework with the lack of regulations } \\
\text { preventing cybercrime }\end{array}$ & 3.32 & 3 & 1 & 5 \\
\hline $\begin{array}{l}\text { Lack of professionals with cybercrime detection abilities, } \\
\text { which determines low fear of punishment }\end{array}$ & 3.37 & 3 & 1 & 5 \\
\hline $\begin{array}{l}\text { Poorly regulated and controlled legal framework of IT } \\
\text { sector }\end{array}$ & 3.42 & 3 & 1 & 5 \\
\hline \multicolumn{5}{|l|}{ Miscellaneous determinants } \\
\hline $\begin{array}{l}\text { IT advantages (convenience, opportunity to make purchases } \\
\text { round-the-clock without leaving home, anonymity) }\end{array}$ & 4.03 & 4 & 1 & 5 \\
\hline $\begin{array}{l}\text { Lack of opportunities to obtain a desired product in the } \\
\text { local market }\end{array}$ & 3.83 & 4 & 1 & 5 \\
\hline $\begin{array}{l}\text { Time saving in comparison to acquisition of a product/ } \\
\text { service in the local market }\end{array}$ & 3.95 & 4 & 1 & 5 \\
\hline
\end{tabular}


Psychological and legal determinants have been found insignificant to acquisition of goods/services from digital shadow market with their low estimated mean ranks.

Further in the research, the respondents were asked to specify the channels, most commonly engaged for acquisition of goods/services from digital shadow markets.

The results revealed that 42 percent of the respondents acquire goods/services from eshops; 37 percent of the respondents use websites for classified adverts such as skelbiu. $l t$, manodrabuziai.lt, etc.; 20 percent of the respondents purchase goods/services from the suppliers operating in social platforms.

The categories of goods/services, acquired in digital shadow markets via the channels mentioned above, cover clothing and footwear (as it was marked by 27 percent of the respondents), trips and entertainment (as it was pointed out by 23 of the respondents), cosmetics and perfume (as it was indicated by 19 percent of the respondents) (see Figure 1).

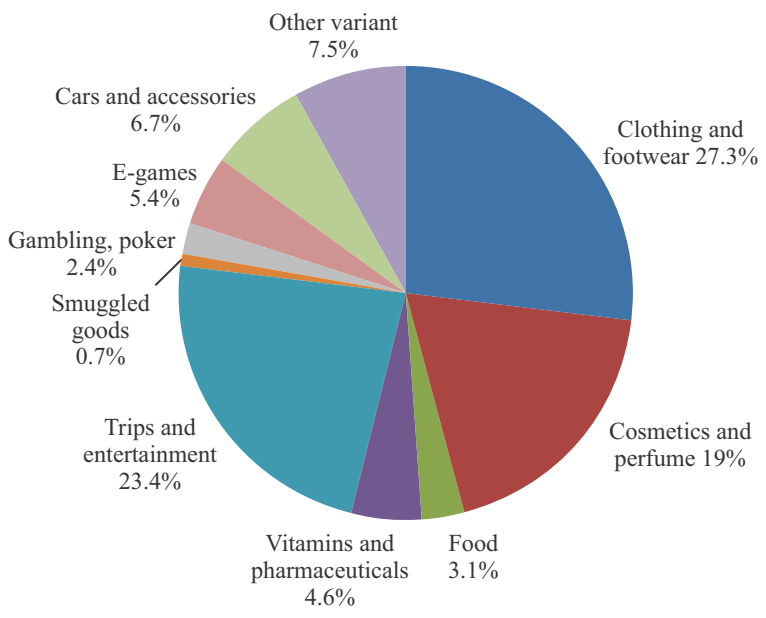

Fig. 1. The categories of the goods/services acquired via the channels of digital shadow consumption, percent (compiled by the authors with reference to the results of the survey)

It is important to note that smuggled cigarettes, alcohol and other kinds of illegal goods/ services are acquired only by the minority ( 0.7 percent) of the respondents, which proposes that e-space is not the basic channel for acquisition of illegal goods/services. Summarizing, it could be concluded that consumers are inclined to distinguish the digital shadow economy from cybercrime, and treat it as an illegal operation in the Internet space, which generates illegal money flows for commodity/service providers or purchasers, and deprives legal traders/service providers from the revenue that could be officially accounted, calculated and declared. The most significant determinants of acquisition of goods/services from digital shadow markets include lower prices, unfavourable economic situation in the country, general technological advancement, IT advantages, time saving in comparison to acquisition of a product/service in the local market, and lack 
of opportunities to obtain a desired product in the local market. Hence, the demand for goods/services, acquired from digital shadow markets, is mainly driven by economic determinants. E-shops, social networks and websites are the channels, most commonly employed for acquisition of goods/services in digital space; the categories of goods/ services acquired by these channels include clothing and footwear, trips and entertainment, cosmetics and perfume.

\section{Conclusions}

The research has enriched the theory of shadow economy with the concept of digital shadow economy from consumers' position. It has been established that digital shadow economy refers to an illegal operation in the Internet space, which generates illegal money flows for commodity/service providers or purchasers, and deprives legal traders/ service providers from the revenue that could be officially accounted, calculated and declared.

The research of the scientific literature has disclosed that digital shadow economy in its general sense refers to illegal, unreported or unrecorded activities online, driven by profit, tax evasion, gain or circumvention of legal regulations, excluding cybercriminal activities as the latter refer to criminal offenses rather than to economy generators.

The empirical research has revealed a clear consumers' perception that the concept of digital shadow economy should be distinguished from the concept of criminal activities. E-shops, social networks and websites are the channels, most commonly engaged for acquisition of goods/services in digital space, and the categories of goods/services acquired by these channels cover clothing and footwear, trips and entertainment, cosmetics and perfume.

Purification of the concept of digital shadow economy from consumers' position enables to formulate the concept of digital shadow economy, which is a significant contribution to the evolution of the theory of digital shadow economy, and can enable to develop an instrument for measuring the scopes of digital shadow economy in further research. The further research may cover estimation of the share of digital shadow economy in the scope of traditional shadow economy. Deviation of the results is the basic limitation of this research. Hence, to alleviate the problem of deviation, it would be purposeful to conduct a representative survey in future studies on the topic of digital shadow economy. Considering practical implementation of the research results, it should be noted that they are topical to the authorities empowered to fight with shadow economy since the research has enabled to identify the main channels of digital shadow economy, through which illegal transactions in e-space are commonly made. What is more, the research has disclosed that the largest part of consumers are not inclined to check the status of an e-entrepreneur, which, undoubtedly, serves as an extra motive to avoid official registration of e-business. Hence, the task of the authorities is to develop the measures aimed at elimination of this motive 


\section{Funding}

This work was supported by the Research Council of Lithuania [grant number MIP15642].

\section{Disclosure statement}

The authors of this article do not have any competing financial, professional, or personal interests from other parties.

\section{References}

Akintoye, K. A.; Araoye, O. E. 2011. Combating e-fraud on electronic payment system, International Journal of Computer 25(8): 48-53.

Alm, J.; Torgler, B. 2011. Do ethics matter? Tax compliance and morality, Journal of Business Ethics 101(4): 635-651. https://doi.org/10.1007/s10551-011-0761-9

Amasiatu, C. V.; Shah, M. H. 2014. First party fraud: a review of the forms and motives of fraudulent consumer behaviours in e-tailing, International Journal of Retail \& Distribution Management 42(9): 805-817. https://doi.org/10.1108/IJRDM-05-2013-0112

Arango, J.; Baldwin-Edwards, M. 2014. Immigrants and the informal economy in Southern Europe. 2nd ed. London: Frank Cass.

Atkinson, R.; Flint, J. 2001. Accessing hidden and hard-to-reach populations: snowball research strategies [online], [cited 25 November 2015]. University of Surrey. Available from Internet: http://sru.soc.surrey.ac.uk/SRU33.pdf

Blackledge, J. M.; Coyle, E. 2010. E-fraud prevention based on the self-authentication of edocuments, Digital Society 10: 329-338. https://doi.org/10.1109/icds.2010.66

Bossler, A. M.; Holt, T. J. 2012. Patrol officers' perceived role in responding to cybercrime, Policing 35(1): 165-181. https://doi.org/10.1108/13639511211215504

Camarero, C.; Anton, C.; Rodriguez, J. 2014. Technological and ethical antecedents of e-book piracy and price acceptance: evidence from the Spanish case, The Electronic Library 32(4): 542-566. https://doi.org/10.1108/EL-11-2012-0149

Castro, D.; Bennett, R.; Andes, S. 2009. Steal these policies: strategies for reducing digital piracy [online], [cited 18 November 2015]. The Information Technology and Innovation Foundation. Available from Internet: www.itif.org/files/2009-12-15.DigitalPiracy.pdf

Dion, M. 2011. Corruption, fraud and cybercrime as dehumanizing phenomena, International Journal of Social Economics 38(5): 466-476. https://doi.org/10.1108/03068291111123156

ECS. 2016. Sample size computation for population proportion confidence interval [online], [cited July 11 2016]. Eberly College of Science. Available from Internet: https://onlinecourses. science.psu.edu/stat500/node/31

Feige, E. F.; Urban, I. 2008. Measuring underground (unobserved, non-observed, unrecorded) economies in transition countries: can we trust GDP?, Journal of Comparative Economics 36(2): 287-306. https://doi.org/10.1016/j.jce.2008.02.003

Feige, E. L. 2007. The underground economies - tax evasion and information distortion. 2nd ed. Cambridge: Cambridge University Press.

Feige, E. L. 2012. New estimates of U.S. currency abroad, the domestic money supply and the unreported economy, Crime, Law and Social Change 57(3): 239-263.

https://doi.org/10.1007/s10611-011-9348-8 
Gaertner, W.; Wenig, A., 2012. The economics of the shadow economy. 1st ed. Berlin: SpringerVerlag.

Hafezieh, N.; Akhavan, P.; Eshraghian, F. 2011. Exploration of process and competitive factors of entrepreneurship in digital space: a multiple case study in Iran, Education, Business and Society: Contemporary Middle Eastern Issues 4(4): 267-279. https://doi.org/10.1108/17537981111190051

Harris, L. C.; Daunt, K. 2013. Managing customer misbehaviour: challenges and strategies, Journal of Services Marketing 27(4): 281-293. https://doi.org/10.1108/08876041311330762

Herley, C.; Florencio, D. 2010. Nobody sells gold for the price of silver: dishonesty, uncertainty and the underground economy [online], [cited 28 November 2015]. Springer Link. Available from Internet: http://link.springer.com/chapter/10.1007\%2F978-1-4419-6967-5_3\#page-1

Higgins, G. E.; Wolfe, S. E.; Markum, C. D. 2008. Digital piracy: an examination of three measurements of self-control, Deviant Behaviour 29(5): 440-461.

https://doi.org/10.1080/01639620701598023

Ho, J.; Weinberg, C. B. 2011. Segmenting consumers of pirated movies, Journal of Consumer Marketing 28(4): 252-260. https://doi.org/10.1108/07363761111143141

Holz, T.; Engelberth, M.; Freiling, F. 2009. Learning more about the underground economy: a case-study of keyloggers and dropzones, in M. Backes, P. Ning. (Eds.). Computer Security ESORICS 2009. ESORICS 2009. Lecture Notes in Computer Science, vol. 5789. Springer, Berlin, Heidelberg. https://doi.org/10.1007/978-3-642-04444-1_1

Ingram, J. R.; Hinduja, S. 2008. Neutralizing music piracy: an empirical examination, Deviant Behavior 29(4): 334-366. https://doi.org/10.1080/01639620701588131

Karanfil, F. 2008. Energy consumption and economic growth revisited: does the size of unrecorded economy matter?, Energy Policy 36(8): 3029-3035. https://doi.org/10.1016/j.enpol.2008.04.002

Levi, M.; Williams, M. L. 2013. Multi-agency partnerships in cybercrime reduction, Information Management \& Computer Security 21(5): 420-443. https://doi.org/10.1108/IMCS-04-2013-0027

Levin, A.; Dato-on, M. C.; Manolis, C. 2007. Deterring illegal downloading: the effects of threat appeals, past behaviour, subjective norms, and attributions of harm, Journal of Consumer Behaviour 6(2/3): 111-122. https://doi.org/10.1002/cb.211

Lithuanian Department of Statistics. 2014. Informacinès visuomenès plètros 2014 metu apžvalga [The review of information society development for 2014] [online], [cited 15 July 2015]. The Committee of Information Society Development. Available from Internet: statistika.ivpk.lt/ ataskaitos/atsisiusti/4050

Lithuanian Free Market Institute (LFMI). 2014. Lietuvos šešèline ekonomika [Lithuanian shadow economy] [online], [cited 23 November 2015]. Free Market Institute. Available from Internet: http://files.lrinka.lt/Seseline_ekonomika/LSE3.pdf

Malhotra, N. K.; Birks, D. F. 2003. Marketing research: an applied approach. 2nd ed. New York: Pearson Education.

Mayayise, T.; Osunmakinde, I. O. 2014. E-commerce assurance models and trustworthiness issues: an empirical study, Information Management \& Computer Security 22(1): 76-96.

https://doi.org/10.1108/IMCS-01-2013-0001

McMillan Dictionary. 2015. The term of e-fraud economy [online], [cited 20 November 2015]. McMillan Online Dictionary. Available from Internet: http://www.macmillandictionary.com/dictionary/british/e-fraud

Moore, T.; Clayton, R.; Anderson, R. 2009. The economics of online crime, Journal of Economic Perspectives 23(3): 3-20. https://doi.org/10.1257/jep.23.3.3

Putniņš, T. J.; Sauka, A. 2014. Shadow economy index for the Baltic countries 2009-2013 [online], [cited 15 March 2015]. The Centre for Sustainable Business at Stockholm School of Eco- 
nomics in Riga. Available from Internet: http://www.sseriga.edu/en/centres/csb/shadow-economyindex-for-baltics/

Schneider, F.; Buehn, A. 2013. Estimating the size of the shadow economy: methods, problems and open questions [online], [cited 10 December 2015]. The Institute for the Study of Labor. Available from Internet: http://www.economics.jku.at/papers/2013/wp1320.pdf

Schneider, F.; Buehn, A.; Montenegro, C. 2010. New estimates for the shadow economies all over the world, International Economic Journal 24(4): 443-461.

https://doi.org/10.1080/10168737.2010.525974

Schneider, F.; Raczkowski, K.; Mróz, B. 2015. Shadow economy and tax evasion in the EU, Journal of Money Laundering Control 18(1): 34-51.

https://doi.org/10.1108/JMLC-09-2014-0027

Shang, R.; Chen, Y.; Chen, P. 2008. Ethical decisions about sharing music files in the P2P environment, Journal of Business Ethics 80(2): 349-365. https://doi.org/10.1007/s10551-007-9424-2

Sirkeci, I.; Magnusdottir, L. B. 2011. Understanding illegal music downloading in the UK: a multi-attribute model, Journal of Research in Interactive Marketing 5(1): 90-110.

https://doi.org/10.1108/17505931111121543

Smith, G. S. 2015. Management models for international cybercrime, Journal of Financial Crime 22(1): 104-125. https://doi.org/10.1108/JFC-09-2013-0051

Sukytè, R. 2010. Elektroninès komercijos vystymosi tendencijos Lietuvoje ir kitose ES šalyse [The tendencies of the development of electronic commerce in Lithuania and other EU states] [online], [cited 11 December 2015]. Northern Lithuania College. Available from Internet: http://www.slk. lt/studentu-konferencijos/2010/articles/PDF/15_VVs_SLK_R.\%20Sukyte.pdf

Vlachos, V.; Minou, M.; Assimakopouos, V.; Toska, A. 2011. The landscape of cybercrime in Greece, Information Management \& Computer Security 19(2): 113-123.

https://doi.org/10.1108/09685221111143051

Waterman, D.; Ji, S. W.; Rochet, L. R. 2007. Enforcement and control of piracy, copying and sharing in the movie industry, Review of Industrial Organisation 30(4): 255-289.

https://doi.org/10.1007/s11151-007-9136-x

Williams, C. C. 2014. Confronting the shadow economy: evaluating tax compliance behaviour and policies. 2nd ed. Cheltenham: Edward Elgar. https://doi.org/10.4337/9781782546047

Williams, C. C.; Franic, J.; Dzhekova, R. 2014. Explaining the undeclared economy in Bulgaria: an institutional asymmetry perspective, South East European Journal of Economics and Business Volume 9(2): 33-45. https://doi.org/10.2478/jeb-2014-0008

Williams, C. C.; Horodnic, I. A. 2015. Evaluating the prevalence of the undeclared economy in Central and Eastern Europe: an institutional asymmetry perspective, European Journal of Industrial Relations 21(4): 389-406. https://doi.org/10.1177/0143831X14568835

Williams, C. C.; Vorley, T. 2014. Institutional asymmetry: how formal and informal institutions affect entrepreneurship in Bulgaria, International Small Business Journal 33(8): 840-861.

https://doi.org/10.1177/0266242614534280

Williams, P.; Nicholas, D.; Rowlands, I. 2010. The attitudes and behaviours of illegal downloaders, Aslib Proceedings 62(3): 283-301. https://doi.org/10.1108/00012531011046916

Yip, M.; Shadbolt, N.; Tiropanis, N.; Webber, C. 2012. The digital underground economy: a social network approach to understanding cybercrime [online], [cited 28 October 2015]. University of Southampton. Available from Internet: http://eprints.soton.ac.uk/343351/4/yip_de2012.pdf Yu, C. P.; Young, M. L.; Ju, B. C. 2015. Consumer software piracy in virtual communities: an integrative model of heroism and social exchange, Internet Research 25(2): 317-334.

https://doi.org/10.1108/IntR-08-2013-0187 
Ligita GASPARÉNIENE் (Prof. Dr) links her research fields to the analysis of macroeconomic phenomenon's, practical decisions of outsourcing and estimation of shadow economy. In 2009, she defended the doctoral thesis on the topic "The impact on transaction costs on outsourcing contracts" (the field of economics, social sciences). During the period of 2005-2015, the researcher has published over 40 scientific articles and issued two monographs titled "The methodology of the estimation of external service transaction costs" and "Estimation of financial investment and investment projects". The basic fields of her scientific work include transaction costs, shadow economy, real estate economy. Ligita Gasparèniene participated in 3 chartered national projects and is currently involved in the scientific national (Lithuanian) project "Digital shadow economy" as the principal researcher.

Rita REMEIKIENĖ (Assoc. Prof. Dr) has accumulated much scientific experience in the research of self-employment and business environment conditions in transition economies. In 2012, she defended the doctoral thesis on the topic "The factors of self-employment in transition economies" (the field of economics, social sciences), which won Lithuanian Science Council's award for the best research in the field social sciences. During her scientific career, Rita Remeikiene has prepared and published over 40 scientific articles ( 6 of which were included in ISI basic list issues; 7 - in ISI database referred issues; 14 - in international databases referred issues, etc.). The main topics of the research are linked to the issues of expansion of opportunities in the labour market, shadow economy, outsourcing, gender gaps, and entrepreneurship. Previously, Rita Remeikiené participated in 3 chartered national projects and led the study project "Nord Plus Horizontals". At present, she is leading the scientific national (Lithuanian) project "Digital shadow economy".

Friedrich Georg SCHNEIDER (Prof. Dr) links his research fields to the analysis of general economic policy, public finance, shadow economy, organized crime, environmental economics, privatization and deregulation policies, public choice. He has a consulting experience (studies, projects) for Austrian industries, Federal Austrian Chamber of Commerce, Federal Austrian Ministry of Economics, Federal Austrian Ministry of Finance, National Central Bank of Germany, Austria, Bank Austria, Brussels EU Commission, World Bank. From 1974 until 2015 professor wrote 74 books, 215 articles in scientific journals, 187 articles in Edited Volumes and Readers. 